\title{
Revealed Comparative Advantage of Ethiopian Leather Industry with Selected African Economies
}

\author{
Mulat Alubel Abtew \\ Ethiopian Institute of Textile and Fashion Technology [EiTEX], Bahir Dar University, Bahir Dar, Ethiopia
}

Email address:

mulat_a@yahoo.com

To cite this article:

Mulat Alubel Abtew. Revealed Comparative Advantage of Ethiopian Leather Industry with Selected African Economies. International Journal of Business and Economics Research. Vol. 4, No. 5, 2015, pp. 229-237. doi: 10.11648/j.ijber.20150405.11

\begin{abstract}
The aim of this paper is to analyze the growth pattern of trade flow and trade comparative advantages of the leather industry products between some selected African economies-Kenya, Egypt, Tunisia and with particular focus on Ethiopia between 2004 to 2013. In doing so, it has been calculated the Balassa index of revealed comparative advantage using industry data at the HS 2-digit level. The studies mainly focus on the two articles of Ethiopian leather export namely, Product: 41 raw hides and skins (other than furskins) and leather, and Product: 42 Articles of leather, animal gut, harness, travel goods. An in-depth revealed comparative advantage (RCA) has been conducted for these two categories separately and the analysis shows that Ethiopia has a comparatively high RCA in raw hide and skin exports over the selected economies during the period of study. Even if RCA index for leather and leather products is less than one, a very promising trend has been observed, as index has been increased about 3,395\% in the studied time. This indicates that Ethiopia has significant potentiality for specialization in leather export both in raw hides and skins and leather product. The paper also highlights that all stakeholder in the country has to work very closely to boost the performance of the leather industry export in the light of evidence. Therefore, investors, entrepreneurs and policy makers should specialize in both raw hides and skins and leather and leather productions and exports to generate more export revenues for the country.
\end{abstract}

Keywords: Revealed Comparative Advantage, Ethiopia, Raw Hide and Skin, Leather and Leather Products, Balassa Index, Exports

\section{Introduction}

Africa is fast emerging as one of the future markets for sourcing quality leather and hides for the booming global leather industry. Leather and leather products are among the most widely traded and universally used commodities in the world. Already, the total value of annual trade is estimated at 1.5 times the value of the meat trade; more than five times that of coffee and more than eight times that of rice. Formal international trade in leather and leather goods is estimated at over US\$ 50 billion a year and the market is far from saturated. In the next decade, the demand for leather raw materials (hides) and finished products may exceed supply - making the leather industry one of the most lucrative business sectors in the years to come.

Africa's abundance of livestock represents a natural strength for the sector, as leather is a by-product of the meat industry. Africa has about 15 per cent of the world's cattle population, a percentage that grew by about a quarter over the last decade, overtaking the global trend. Similarly, Africa possesses about 25 per cent of the world's sheep and goat population. This puts African at the centre of the booming leather industry as a key supplier of hides and raw materials to the growing industry of leather and leather goods. However, despite its significance as a livestock producer, Africa accounts for only eight per cent of world production of cattle hides and about 14 per cent of goat and sheepskins. Further, even though African countries often rank leather high in importance as an export commodity, leather and leather products generally account for less than four per cent of total exports. However, things are now changing rapidly as more and more countries around the world are looking to source their requirements for leather and hides from African countries.

Comparative advantage is important concept in modern economic theory. Comparative advantage is a concept more than 200 years old that are immovable until today and is considered determinant of specialization in the concept of international trade. Liesner (1958) is the first person who introduced the measurement of reveal comparative advantage 
(RCA), and later developed by Balassa (1965). Balassa (1965; 1977 ; 1989) have published and analyzed of revealed comparative advantage measure in manufacturing and across industries. Comparative advantage measure is determinant of trade pattern which leads to the international trade specialization and to be determined by several supply and demand factors. Comparative advantage will increase the efficiency of scarce resources and welfare.

Comparative advantage is also the term used to describe the notion that, a country should specialize in the production of those goods that they can produce in lower opportunity cost than others. In other words, a country can produce its products with different level of cost per unit of production. They should specialize in the production of those goods that they can produce with lower relative cost than other countries. And then with international trade, country can obtain other goods at a lower price (opportunity cost), in exchange for the good in which it has a comparative advantage [1]. While, Ricardian theory stated comparative advantage due to technological dissimilarities across nations, H-O theory considers cost dissimilarities arising due to differences in factor prices across nations, assuming constant technology.

Different theoretical procedure to "reveal" a country's comparative advantage using a variety of techniques are used. Among these, focusing estimation of comparative advantage of any country rather than focusing on determining its sources, Balassa [2] provided a measure to identify a country's revealed comparative advantage named Balassa Index. This study is aim to "reveal" the comparative advantage of leather industry of Ethiopia, if any, in comparison to other selected African countries- Kenya, Egypt and Tunisia. This study, focus on export data of leather industry of Ethiopia- both in Raw hides and skins (other than furskins) and leather, and leather goods with selected countries to answer the question of whether Ethiopia should devote its more scarce resources to leather industry or not.

This paper will try to determine comparative advantage using the International Trade data to compare exports of Ethiopian leather industry with the selected African economies and try to answer the countries having a better comparative advantage will export in higher proportion relative to the other mentioned countries. After this chapter, chapter two will discuss the relevant literature related to the paper, the chapter three presents the overall overview and current status of Ethiopian leather industry; chapter four will give the methods to determine the revealed comparative advantages of the countries; chapter five will analyze the data using the methods and the final chapter will give the conclusion about the study.

\section{Literature Review}

Leather is one of the most widely traded commodities in the world. The leather and leather products industry plays a prominent role in the world's economy, with an estimated global trade value of approximately US $\$ 100$ billion per year [18]. It has also been the case that countries with good raw material supplies, such as India and Brazil, have continued to grow their industries successfully all the way to the finished product stage. It has been expect that this trend will continue in places such as Ethiopia and Pakistan, which are joining the group of countries determined to achieve high levels of competence and employment in the leather industry by capitalizing on indigenous resources [3].

Ethiopia's footwear industry and its leather sector in general enjoy significant international comparative advantages owing to its abundant and available raw materials, highly disciplined workforce and cheap prices. Ethiopia is endowed with a very large and diverse livestock resource in the world. Ethiopia's livestock population was estimated to be 44.3 million cattle, 23.6 million sheep and 23.3 million goats. Based on the offtake rate of $7.0 \%, 33.0 \%$ and $35.0 \%$ for cattle, sheep and goat respectively. So, expecting to produce 3.1 million hide, 7.8 million sheep skin and 8.2 million goat skins [4], the country is ideal for leather production and making leather products.

Beside these export potentiality, however, Ethiopia face lot of challenges and problem in leather sector, which tentatively poses the threat for expansion of leather export. There have been several forms of industrial policies the government has adopted to overcome the constraints the leather sector has faced. Coordination failure arises in the raw hides and skins production and supply due to the strategic complementarities among various facets of production, distribution and trade. Strategic complementarities are best illustrated by the high level of dependency of the product quality of leather processing companies on the quality of raw hides and skins supplied by traders. In a perfectly competitive market set up with thick markets, price signals would reward high quality and hence, producers and traders of sub-standard quality would either be driven out of the market or would be relegated to a distinct low quality-oriented market. Alternatively, in situations with asymmetric market power distribution, there will arise private enterprises that would "ensure coordination of upgrading activities throughout the value chain" [5].

Several studies have been undertaken using the concept of revealed comparative advantage. A majority of these studies use data on export shares. Balassa (1977) has undertaken an analysis of the pattern of comparative advantage of industrial countries for the period 1953 to 1971. Balassa's results show that while the extent of export diversification tends to increase with the degree of technological development a reversal takes place at higher levels. Yeats [6] studies the possible distortions in trade patterns on account of discriminatory trade barriers. He uses the index of revealed comparative advantage in conjunction with the changes in the regional orientation of exports to identify any apparent inefficiency in trade patterns for the Mercosur group of countries. The RCA measure provides signal on the movement in a region's comparative advantage [7].

Studies have also been conducted in selected industry on the basis of assuming regional similarities and advantages over other regions of the world. When Spair [8] focused on trade shares among European countries. In addition to discriminatory trade barriers found in these studies, Richardson and Zhang [9], when compared the trade 
performance of USA with other regional trading partners, found differences due to geographical immediacy of trading partners and per capita income over time and across sectors. Moreover, Bender and $\mathrm{Li}$ [10] also observed related changes in export pattern among different Asian and Latin American regions.

In the context of Ethiopia, such studies of exploring revealed comparative advantages are very few and also keen on general trade export. Among the study, Felix C., Bongani M, and Macleans M.[11] analyses that Ethiopia has comparative advantage in the production of 302 product lines and is benefitting from engaging in international trade with other countries. Among those tanned or crust skins of sheep or lambs tops the product list with the highest index of 1822. This product line is followed by sesamum seeds with an index of 1275. The third position is occupied by goat meat with an index of 907.It is followed by broad beans and horse beans with an index of 830 . The fifth position is occupied by oil seeds and oleaginous fruits with an index of 784 .

However, none of these studies have focused on leather industry of Ethiopia. As a labor-intensive export sector, leather industry of Ethiopia has a comparatively better potentiality for export performance. It indicates the need for an in-depth analysis of this industry to reveal comparative advantage, if any, compare to other selected countries in African countries. The above stated empirical studies on revealed comparative advantage provide rationale for using Balassae ${ }^{\text {ee }}$ [2] measure of relative comparative advantage for leather industry of Ethiopia

Moreover studies in specific country within region are rare. Mudavanhu V, Mzumara M and Tafirei F [12] have investigated competitiveness of Kenyan industries in the world trade using Balassa"s [2] measure of relative export performance by country and industry. The result shows that the most competitive industry in Kenya is textiles. It has 130 product codes with $\mathrm{RCA} \geq 1$, followed by chemicals and allied industries with 109 product codes in which Kenya has competitive advantage. In the third place is plastic/rubber with 106 product codes. In the fourth place is metals and it has 88 product codes in it in which it has competitive advantage. In the fifth place are vegetable products with 84 product codes. There are three less efficient or less competitive industries in Kenya. These are: raw hides, skins, leather and furs; foot wear/head gear; and transportation. Furthermore Paulina M. and Kenneth W [13] analyzed factors affecting value addition in the leather industry in Kenya for better export value.

According to Bouras H. [14] the three Tunisian sectors have revealed comparative advantages with the EU, they are characterized by the indicator of revealed comparative advantage greater than unity, textiles and textile articles, agribusiness and shoes. The ranking of sectors according to their revealed comparative advantage has not experienced significant changes since 1990 . He also analyzed potential competitive Tunisian economy in discussing the potential specialization by calculating the indicators in this area and analyzing the potential for export and analysis of the diversification of Tunisian exports, while a comparison with the countries of the Middle East and North Africa.
Studies also shows that Macroeconomic stability, the openness of the economy, the key role played by the private sector and market forces (degree of competition), and the quality of the infrastructure are the corner stones for a suitable strategy of development of the Leather and Shoes Sector (LSS) in Tunisia. The most important comparative advantage of the Tunisian LSS is the supportive environment and the high quality of the supporting institutions which enable the sector to move from the manufacturing of mass consumer products to high quality and added value ones. [15]

During the period 1998-2000, study shows that Egypt has a strong competitive advantage in exporting long and very longstaple cotton-either as raw cotton fiber or in some finished form. Cotton yarn exports in 2002 were also large at \$129 million. Woven cotton fabrics appear to be even less competitive, with exports declining rapidly. On the other hand, carpets and men's and women's suits have been doing very well, demonstrating significant competitive advantage. In fact, exports of clothing and household textiles have been expanding across a relatively broad front, showing considerable overall strength. [16]

Another study was carried out on evaluation of the Eastern African Manufacturing Sector's competitiveness and comparative advantage including Kenya, Tanzania, Ethiopia, Rwanda, Burundi and Seychelles. Thus, competitiveness involves international comparisons while comparative advantage involves comparisons across domestic industries [17].

\section{Leather Industry in the Selected African Countries}

\subsection{Ethiopian Leather Industry: The Overview}

With an annual off-take rate of nearly $10 \%$ for cattle, $33 \%$ for sheep and $38 \%$ for goats, the country is endowed with enormous potential for cheap supply of skin and hide. There is a clear recognition of this potential by policy makers in Ethiopia as indicated by the Growth and Transformation Plan (GTP) and several other national plans that preceded it. In the country GTP document, the leather and leather products industry is one of the priority industries that are expected to contribute considerably to export diversification and foreign exchange earnings through greater value addition and productivity improvement (FDRE, 2010).

According to MEDaC (1999), the livestock population of the country has risen to $34.1,30.54$, and 21.11 million head of cattle, sheep and goats, respectively, in the year 1998/99, up from the 1993/94 figures of 31.45, 27.5 and 19.76 million head of cattle, sheep and goats, respectively. The annual average growth rate was $1.2,1.4$ and $0.5 \%$, respectively (MEDaC, 1999).

Ethiopia has a long history of handcrafting and blacksmithing. The leather soaking and tanning industry emerged with the establishment of the ASCO tannery (the current Addis Ababa Tannery) in 1918 and Darmar/Awash (currently ELICO) tannery by Armenian traders in 1927. In the 
subsequent years, several local tanneries, such as Dire, Modjo and Kombolcha were set up [18]. The emergency of the modern leather processing industry also dates back to the 1930s, a period associated with the establishments of two shoe factories, Tikure Abbay and Anbessa, by Armenian merchants [19]. In the 1950s and the 1960s, for example, leather and leather goods production were small in volume and largely targeted the local market [20]. In the 1974, all private tanneries were nationalized. The government subsequently established the National Leather and Shoe Corporation, which assumed the responsibility of managing eight tanneries and six shoe factories.

In 1986, the socialist regime banned the export of raw hides and skin in an attempt to encourage the domestic production of semi-processed leather articles. This ban radically altered the marketing structure of hides and skins by restricting exports to at least the wet-blue level. While the ban might have forced hide and skin traders to sell directly to tanneries for processing, it has also encouraged illegal cross-border trade in both live animals and hides and skins. It is by now evident that the ban had a limited impact in improving the local leather tanning and leather goods manufacturing capacity [21].

The Ethiopian leather sector is composed of raw hides and skins traders, leather tanneries, which source their supply mostly from the local market, and footwear producers, who use both local and international markets for raw material supply. The most important source of raw material for leather tanneries are hides and skins that are procured from skin collectors and traders. Larger tanneries that are fitted with machines and equipment to produce leather products higher up in the leather value chain buy semi-processed leather products from other tanneries. The industry produces a variety of types of finished leather, both for domestic use and for export, and leather products, amongst which the most prominent is footwear [22].

Table 1. Export performance of selected African economies in raw hide and skin.

\begin{tabular}{lllll}
\hline $\begin{array}{l}\text { Total Raw hides and skins exports of selected countries (USD } \\
\text { thousands) }\end{array}$ & Ethiopia & Kenya & Egypt & Tunisia \\
\hline Years & Egr & 26724 & 16386 \\
\hline 2004 & 63516 & 29074 & 27077 & 24919 \\
2005 & 66778 & 32681 & 27960 & 17160 \\
2006 & 77693 & 35956 & 37020 & 25546 \\
2007 & 93394 & 47254 & 62511 & 28247 \\
2008 & 90960 & 48611 & 117022 & 20676 \\
2009 & 42769 & 29322 & 152274 & 34069 \\
2010 & 67199 & 53016 & 119266 & 46198 \\
2011 & 122713 & 83404 & 172763 & 47638 \\
2012 & 85608 & - & 195392 & 49110 \\
\hline 2013 & 103422 & 100149 & & \\
\hline
\end{tabular}

Source: ITC, COMTRADE data

In the 1990 s, the privatization policy adopted by the EPRDF government implied that all state-owned (SOEs) tanneries were auctioned off. The liberalization policy also allowed for the flourishing of private tanneries, leather garment and leather goods manufacturing industries. In the footwear sector, for example, the newly established private companies were able to quickly match the production capacity of the then existing large SOEs (some were privatized latter) in early 2000s [19]. In 2008, there were 21 tanneries in Ethiopia with a combined tanning capacity of 4,000 pieces of hide and 30,000 pieces of skin per day. There are now 26 tanneries and more than 15 large export oriented footwear producers and an untold number of micro and small shoemakers in Ethiopia. The tanneries have a combined tanning capacity of more than 170,000 pieces of skins and hides per day, and footwear producers can produce more than 20,000 pairs of shoes per day.

Table 2. Export performance of selected African economies in leather and leather products.

\begin{tabular}{lllll}
\hline $\begin{array}{l}\text { Total leather and leather product exports of selected countries (USD } \\
\text { thousands) }\end{array}$ & Kenya & Egypt & Tunisia \\
\hline Years & Ethiopia & Ky & 1794 & 55758 \\
\hline 2004 & 94 & 967 & 1969 & 59021 \\
2005 & 34 & 1372 & 2662 & 59833 \\
2006 & 12 & 1209 & 2252 & 78538 \\
2007 & 248 & 912 & 12069 & 94346 \\
2008 & 94 & 6404 & 9030 & 68433 \\
2009 & 498 & 1395 & 6728 & 74641 \\
2010 & 640 & 2200 & 6300 & 95605 \\
2011 & 676 & 1967 & 2023 & 91094 \\
2012 & 3010 & - & 3585 & 91583 \\
2013 & 3286 & 2038 & \\
\hline
\end{tabular}

Source: ITC, COMTRADE data

Despite its long pedigree, the leather products industry in Ethiopia has been struggling with limited processing capacity that explains not just the inability of local leather goods producers to penetrate the export market, but also their failure to withstand competition from imports once the economy was liberalized in 1991. Following the liberalization policy of the current regime, for example, the leather footwear sector was inundated with cheap foreign imports in the late 1990s. Perhaps not surprisingly, this had the immediate effect of driving out many footwear producers 'plunging the sector into a slump' in the early 2000s [19]. Helped by improved local capability and effective industrial polices, the sector has since then registered impressive growth that enabled it to reclaim some of the domestic market and even successfully venture into the export market.

Due to the availability of cheap raw materials including hides and skins as well as labor, the leather and leather products industry(LLPI) has been one of the sectors in which a range of industrial policies were introduced. This is because of the presence of wide ranging and mutually reinforcing problems at several stages of the leather value chain that have kept production volume and quality low [5]. The government has thus devised polices to improve the supply and quality of raw materials and has sought to stabilize their prices. Efforts have also been made to upgrade the production facilities and techniques of leather processing units while attempting to improve the international marketability of leather products. In short, the government interventions in the industry range from the point of skin and hides collection to the leather production and marketing stages. These were problems that inhibit industrial transformation and growth of the LLPI and that the 
market, left to its own devices, cannot help overcome. Thus proactive state intervention were not only required, they are also now recognized to have brought about extensive progress in the leather industry. [22]

Table 3. Growth in the value of raw hide and skin exports.

\begin{tabular}{lllll}
\hline \multicolumn{6}{l}{ Growth of Exports in value (\%) } \\
\hline Years & Ethiopia & Kenya & Egypt & Tunisia \\
\hline 2004 & 5 & 12 & 1 & 52 \\
2005 & 16 & 10 & 3 & -31 \\
2006 & 20 & 31 & 32 & 49 \\
2007 & -3 & 3 & 69 & 11 \\
2008 & -53 & -40 & 87 & -27 \\
2009 & 57 & 81 & 46 & 65 \\
2010 & 83 & 57 & -11 & 36 \\
2011 & -30 & - & -22 & 3 \\
2012 & 21 & - & 45 & 3 \\
2013 & -13 & - & 13 & - \\
\hline
\end{tabular}

Source: ITC, COMTRADE data

Table 4. Growth in the value of leather and leather products exports.

\begin{tabular}{lllll}
\hline \multicolumn{6}{l}{ Growth of Exports in value (\%) } \\
\hline Years & Ethiopia & Kenya & Egypt & Tunisia \\
\hline 2004 & -64 & 42 & 10 & 6 \\
2005 & -65 & -12 & 35 & 1 \\
2006 & 1967 & -25 & -15 & 31 \\
2007 & -62 & 602 & 436 & 20 \\
2008 & 430 & -78 & -25 & -27 \\
2009 & 29 & 58 & -25 & 9 \\
2010 & 6 & -11 & -6 & 28 \\
2011 & 345 & - & -68 & -5 \\
2012 & 9 & - & 77 & 1 \\
2013 & 50 & - & -19 & - \\
\hline
\end{tabular}

Source: ITC, COMTRADE data

\subsection{The Total Leather Export Picture of Selected African Countries}

The above table, Table 1, Table 2, Table 3 and Table 4, shows the export status of total Ethiopian leather industry in comparison with other selected African countries. Table 1 and Table 2 represents exports performance of Ethiopia, Kenya, Egypt and Tunisia in raw hide and skins and leather, and Leather products from 2004 to 2013 time period respectively. During this time, Table 2, shows total Ethiopian leather and leather product export has been increased more than 3,396\%, and other selected African countries are also showing similar trend in some extent, for example Kenya $110.75 \%$, Egypt $99.8 \%$ and Tunisia 64\%. Meanwhile in raw hide and skin product export category, indicated in Table 1, Ethiopia increased by $62.8 \%$ and the selected countries, Kenya 244\%, Egypt $631 \%$ and Tunisia 199.7\%. However, these growth patterns are not same for all selected countries, over the period. The growth pattern in the value of raw hide and skin export and leather, and leather product exports for the countries are presented in the Table 3 and Table 4 respectively.

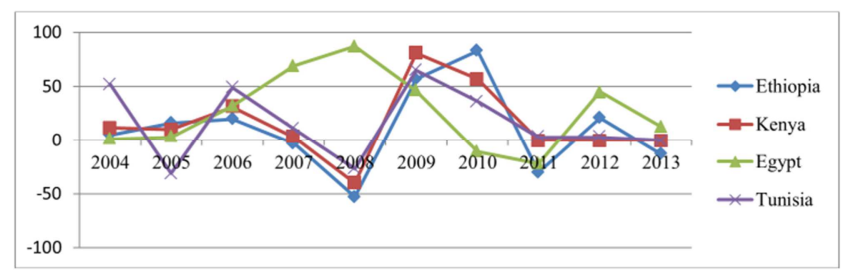

Figure 1. Growth pattern in raw hide and skin export for selected African countries.

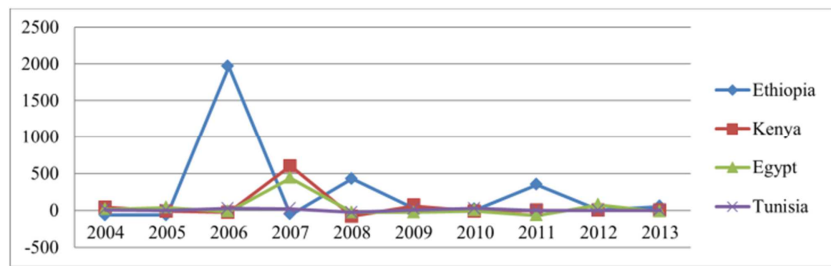

Figure 2. Growth pattern in leather products export for selected African countries.

For Ethiopia, the growth rate is very unstable with sharp ups and down, which is quite similar with the other four selected African countries. More over both countries experienced positive and negative growth over the selected period whereas selected countries except Ethiopia experienced a sharp negative growth in 2008 and unlike other countries Ethiopia face a negative growth in 2007. Ethiopia experienced highest growth rate in 2006, Kenya and Egypt in 2007 whereas Tunisia in 2010. Ethiopia face negative growth rate in 2004, 2005 and 2007. However, Egypt and Tunisia have a negative growth in very recent year in 2011. The inconsistent surges for the two category growth for selected countries are also plotted in Fig. 1 and Fig. 2.

Table 5. Raw hide and skins export shares in country total exports \& world's total export.

\begin{tabular}{|c|c|c|c|c|c|c|c|c|}
\hline Years & Ethiopia & & Kenya & & Egypt & & Tunisia & \\
\hline & $\begin{array}{l}\text { \% of Total } \\
\text { Export } \\
\end{array}$ & $\begin{array}{l}\text { \% of World } \\
\text { Total Export }\end{array}$ & $\begin{array}{l}\text { \% of Total } \\
\text { Export } \\
\end{array}$ & $\begin{array}{l}\text { \% of World } \\
\text { Total Export }\end{array}$ & $\begin{array}{l}\text { \% of Total } \\
\text { Export } \\
\end{array}$ & $\begin{array}{l}\text { \% of World } \\
\text { Total Export }\end{array}$ & $\begin{array}{l}\text { \% of } \\
\text { Total Export }\end{array}$ & $\begin{array}{l}\text { \% of World } \\
\text { Total Export }\end{array}$ \\
\hline 2004 & 10.33 & 0.2 & 1.08 & 0.1 & 0.35 & 0.1 & 0.17 & 0.1 \\
\hline 2005 & 7.21 & 0.3 & 0.96 & 0.1 & 0.25 & 0.1 & 0.24 & 0.1 \\
\hline 2006 & 7.45 & 0.3 & 1.03 & 0.1 & 0.2 & 0.1 & 0.15 & 0.1 \\
\hline 2007 & 7.31 & 0.3 & 1.16 & 0.1 & 0.23 & 0.1 & 0.17 & 0.1 \\
\hline 2008 & 5.68 & 0.3 & 0.97 & 0.2 & 0.24 & 0.2 & 0.15 & 0.1 \\
\hline 2009 & 2.64 & 0.2 & 0.66 & 0.1 & 0.48 & 0.6 & 0.14 & 0.1 \\
\hline 2010 & 2.88 & 0.2 & 1.03 & 0.2 & 0.65 & 0.6 & 0.21 & 0.1 \\
\hline 2011 & 4.69 & 0.4 & 1.42 & 0.3 & 0.48 & 0.5 & 0.26 & 0.1 \\
\hline 2012 & 2.96 & 0.3 & - & - & 0.41 & 0.4 & 0.28 & 0.1 \\
\hline 2013 & 2.54 & 0.3 & 1.81 & 0.3 & 0.6 & 0.5 & 0.29 & 0.1 \\
\hline
\end{tabular}

Source: ITC, COMTRADE data 
Table 6. Leather product Export shares in total Exports and world's total leather product Exports.

\begin{tabular}{|c|c|c|c|c|c|c|c|c|}
\hline Years & Ethiopia & & Kenya & & Egypt & & Tunisia & \\
\hline & $\begin{array}{l}\text { \% of Total } \\
\text { Export }\end{array}$ & $\begin{array}{l}\text { \% of World } \\
\text { Total Export }\end{array}$ & $\begin{array}{l}\text { \% of Total } \\
\text { Export }\end{array}$ & $\begin{array}{l}\text { \% of World } \\
\text { Total Export }\end{array}$ & $\begin{array}{l}\text { \% of Total } \\
\text { Export }\end{array}$ & $\begin{array}{l}\text { \% of World } \\
\text { Total Export }\end{array}$ & $\begin{array}{l}\text { \% of } \\
\text { Total Export }\end{array}$ & $\begin{array}{l}\text { \% of World } \\
\text { Total Export }\end{array}$ \\
\hline 2004 & 0.02 & 0 & 0.04 & 0 & 0.02 & 0 & 0.58 & 0.2 \\
\hline 2005 & 0 & 0 & 0.04 & 0 & 0.02 & 0 & 0.56 & 0.2 \\
\hline 2006 & 0 & 0 & 0.03 & 0 & 0.02 & 0 & 0.51 & 0.2 \\
\hline 2007 & 0.02 & 0 & 0.02 & 0 & 0.01 & 0 & 0.52 & 0.2 \\
\hline 2008 & 0.01 & 0 & 0.13 & 0 & 0.05 & 0 & 0.49 & 0.2 \\
\hline 2009 & 0.03 & 0 & 0.03 & 0 & 0.04 & 0 & 0.47 & 0.2 \\
\hline 2010 & 0.03 & 0 & 0.04 & 0 & 0.03 & 0 & 0.45 & 0.1 \\
\hline 2011 & 0.03 & 0 & 0.03 & 0 & 0.02 & 0 & 0.54 & 0.1 \\
\hline 2012 & 0.1 & 0 & - & 0 & 0.01 & 0 & 0.54 & 0.1 \\
\hline 2013 & 0.08 & 0 & 0.04 & 0 & 0.01 & 0 & 0.54 & 0.1 \\
\hline
\end{tabular}

Source: ITC, COMTRADE data

In Table 5 and 6 percentage of raw hide and skin and leather product to country's total export and to world's total export respectively are presented for selected four countries over the period of 2004-2013. And Fig.3 and Fig. 4 shows the share of total raw hide and leather product exports respectively, as percentage of total countries export.

On the category one, raw hide and skins, Ethiopia export shares only $0.27 \%$ of world's export and accounts $5.15 \%$ of country's total export earnings, which is higher than the selected countries, in 2004-2013 by the later. On the other hand, in Kenya, the export share accounts $1.27 \%$ on average of its total export earnings, but it serve only $0.19 \%$ of total world's export. Both Egypt and Tunisia serve below 1\% on both averages of world's total export and of their total export earnings. (Table 5 and Fig. 3)

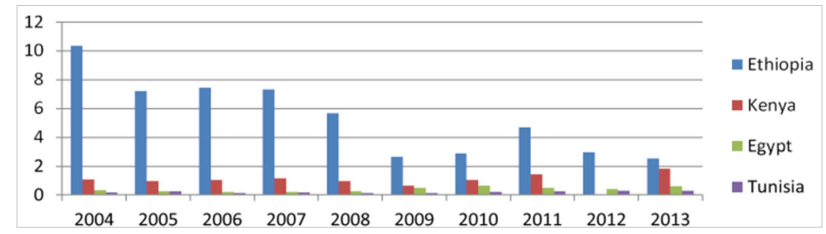

Figure 3. Raw hide and skin export as \% of total domestic exports of the countries.

On the category two, leather and leather product, Ethiopia, Kenya and Egypt exports became negligible (almost 0\%) of world's export and accounts less than $0.1 \%$ of country's total export earnings. However Tunisia serve $0.1 \%$ on world's total export and $0.21 \%$ of their total export earnings, which is higher than the selected any countries in this category. (Table 6. and Fig. 4)

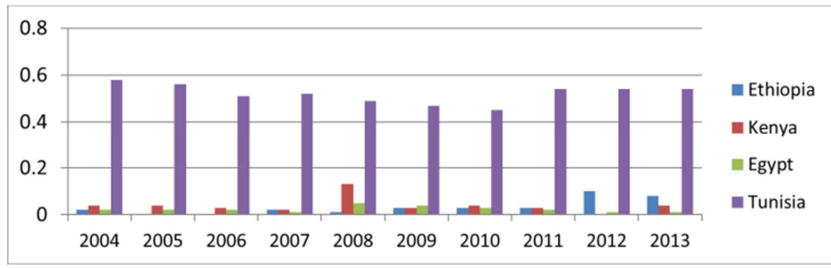

Figure 4. Leather and leather product export as \% of total domestic exports of the countries.

In the Ethiopian context, however, the market is neither 'perfectly competitive' nor is there any large private entity with manifested interest in coordinating activities along the leather value chain. To start with, the market for raw hides and skin appears to be highly segmented with a large number of unorganized producers and traders in different regions. More precisely, the vast majority of raw hides and skins production comes from non-commercial individual producers and traders in rural areas and both producers and traders are highly unorganized and operate outside of the formal business sector, the export growth of Ethiopian leather industry could not match its true potentials till now.

\section{Methodology}

Vollrath (1991) offered three alternative specifications of revealed comparative advantage, following analyses of international competitiveness in agriculture (Vollrath, 1987 and 1989; and Vollrath and Vo, 1990).The first of these measures is the relative trade advantage (RTA), which accounts for imports as well as exports. It is calculated as the difference between relative export advantage (RXA), which equates to the Balassa index1, and its counterpart, relative import advantage (RMA).

Relative Comparative advantages (RCA) indices evaluates export performance as the total exports of a specific product, divided by the total exports of that country compared to the world exports of the product, divided by total world exports. Actually there are couples of techniques to measure a country's revealed comparative advantage. One is Balassa's [2][23][24][25] RCA index (denoted as RCA) that compares the export share of a given sector in a country with the export share of that sector in the world market. It is concerns to the relative trade performance of individual countries in particular commodities. The factors that contribute to movements in RCA are economic: structural change, improved world demand and trade specialization [26][27][28]. In this study Balassa's RCA index is used, which is a standard approach or methodology to estimate a country's comparative advantage or comparative disadvantage in commodities, industries or sectors [29].

According to Balassa, 1965, RCA is defined as follows:

$$
\mathrm{RCAij}=(\mathrm{Xij} / \mathrm{Xit}) /(\mathrm{Xwj} / \mathrm{Xwt})
$$


Where,

- RCAij represents the RCA of a given country $i$;

- Xij represents the export volume of product $\mathrm{j}$ in country $\mathrm{i}$;

- Xit represents the total export volume of country $i$;

- Xwj represents the export volume of product $\mathrm{j}$ of the world; and

- Xwt represents the total export volume of the world.

Here the numerator is the share of a country's total exports of the selected product in its total exports. The denominator is share of world exports of the same product in total world exports. The index of revealed comparative advantage (RCAij) has a relatively simple interpretation. It takes a value between 0 and positive infinity. If it takes a value greater than unity, the country has a revealed comparative advantage in that product and a value lower than unity, country has comparative disadvantage in that product. The index might be affected by anything that distorts the trade pattern, e.g., trade barriers. A country reveals comparative advantages in products for which this indicator is higher than 1 , showing that its exports of those products are more than expected on the basis of its importance in total exports of the world. The advantage of using the comparative advantage index is that it considers the intrinsic advantage of a particular export commodity and is consistent with changes in an economy's relative factor endowment and productivity. However, the disadvantages are that it cannot detect the source of comparative advantage or disadvantage, improvements in factor endowments and pursuit of appropriate trade policies by a country [26][1].

Other than the model specifications, major data sources for calculating RCA index are world development indicators (WDI) developed by World Bank and UN COMTRADE for the indicated period of time. In this context, data are collected for Harmonized System (HS) code 41 and 42 for selected number of countries. HS code 41 represents raw hides and skins, whereas HS code 42 represents Leather and leather products. Some other secondary data has been collected from Ethiopian Ministry of Industry, Hides and Skins Marketing Corporation (HSMC), National Leather and Shoe Corporation (NLSC), Ethiopian Tanners Association (ETA), Quality \& Standard Authority of Ethiopia (QSAE),Livestock Marketing Authority (LMA), Quality \& Standard Authority of Ethiopia (QSAE), Ethiopian Tanners Association (ETA) and Leather Industry Development Institute to present the present export scenario of Ethiopian in the mentioned products.

\section{Countries Revealed Comparative Advantage Analysis}

This section of the study is developed to presenting the results of the analysis performed on collected data to determine the pattern of revealed comparative advantage in leather industry for Ethiopia, Kenya, Egypt and Tunisia. An in depth analysis has been configured for sub category of leather industry - Raw hide and skin and Leather and leather products category for the period of 2004 to 2013 .

Table 7. Detail Revealed Comparative Advantage Index for Leather Industry for countries.

\begin{tabular}{|c|c|c|c|c|c|c|c|c|}
\hline Years & Ethiopia & & Kenya & & Egypt & & Tunisia & \\
\hline & $\begin{array}{l}\text { Raw hide and } \\
\text { skin }\end{array}$ & $\begin{array}{l}\text { Leather \& } \\
\text { leather product }\end{array}$ & $\begin{array}{l}\text { Raw hide and } \\
\text { skin }\end{array}$ & $\begin{array}{l}\text { Leather \& } \\
\text { leather product }\end{array}$ & $\begin{array}{l}\text { Raw hide and } \\
\text { skin }\end{array}$ & $\begin{array}{l}\text { Leather \& } \\
\text { leather product }\end{array}$ & $\begin{array}{l}\text { Raw hide and } \\
\text { skin }\end{array}$ & $\begin{array}{l}\text { Leather \& } \\
\text { leather product }\end{array}$ \\
\hline 2004 & 35.31 & 0.043 & 3.70 & 0.10 & 1.19 & 0.07 & 0.58 & 1.63 \\
\hline 2005 & 28.02 & 0.011 & 3.71 & 0.12 & 0.99 & 0.05 & 0.92 & 1.65 \\
\hline 2006 & 30.68 & 0.004 & 4.23 & 0.11 & 0.84 & 0.06 & 0.60 & 1.59 \\
\hline 2007 & 32.07 & 0.060 & 5.08 & 0.07 & 1.00 & 0.04 & 0.74 & 1.61 \\
\hline 2008 & 31.22 & 0.019 & 5.34 & 0.41 & 1.32 & 0.15 & 0.80 & 1.57 \\
\hline 2010 & 14.47 & 0.080 & 5.15 & 0.12 & 2.90 & 0.07 & 1.04 & 1.32 \\
\hline 2011 & 26.22 & 0.071 & 7.96 & 0.09 & 2.11 & 0.06 & 1.45 & 1.48 \\
\hline 2012 & 16.91 & 0.276 & - & - & 3.35 & 0.02 & 1.60 & 1.42 \\
\hline 2013 & 13.27 & 0.202 & 9.46 & 0.09 & 3.55 & 0.03 & 1.51 & 1.35 \\
\hline
\end{tabular}

For the sake of addressing fine understanding, Table 7, shows the comparative view of detail revealed comparative advantage index for sub categories of leather industry for period of 2004 to 2013. The total export categorize of its leather industry in two category- first, Raw hide and skin export and second, Leather and leather products. For category one, raw hide and skin, the results show that, for selected African countries, except Tunisia in the first six years, the revealed comparative advantage index is greater than unity $(\mathrm{RCA}>1)$ which indicates a significant potential growth of these countries raw hides and skins export.

Though, Ethiopia experiencing a decreasing comparative advantage, it is much stable over years and substantially much greater than other countries of the study. In addition, among the selected countries, Kenya shows comparative advantage with interesting insights from year after year. In the contrary to other countries, Tunisia and Egypt has a comparative disadvantage between 2004 to 2009 and 2005 to 2006 respectively in raw hide and skin based on its revealed comparative advantage index (Fig.3).

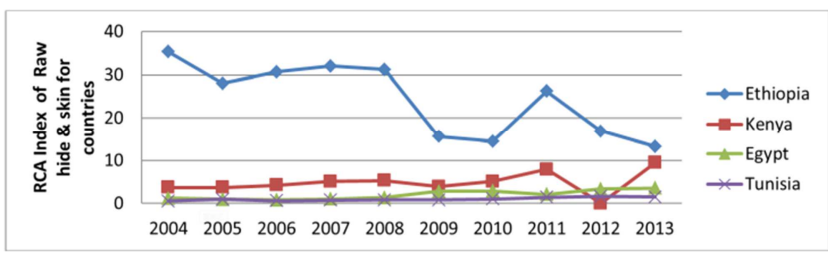

Figure 5. RCA Index comparison for countries in export of raw hide and skin. 


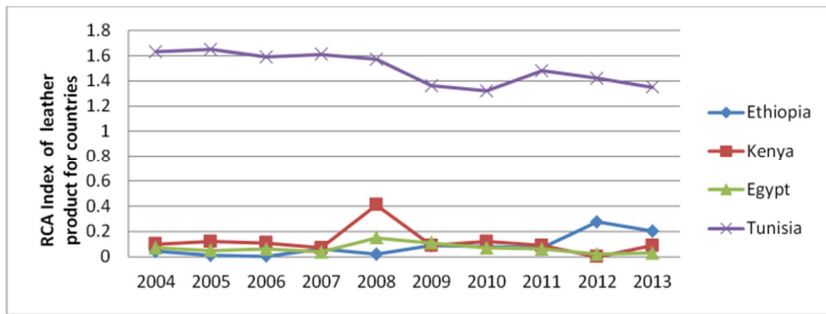

Figure 6. RCA Index comparison for countries in export of raw hide and skin.

For category two, leather and leather product, Tunisia has a revealed comparative advantage in the export of leather and leather product. The index is more than unity and quite stable over years and higher to all other countries. At the same time, Ethiopia, Kenya and Egypt have no comparative advantage in the export of Leather and leather Products category (Fig 4.).

\section{Conclusion}

In this study it has been analyze the performance of leather industry in Ethiopia and made its comparison with selected African countries, Kenya, Egypt and Tunisia. Throughout the study Balassa"s RCA index has been employed to analyze exports of leather industry from year 2004 to 2013. To get clearer picture of this scenario, the research has been extended for the two category of leather industry, for raw hide and skin and Leather and leather products.

From the study results it has been observed that RCA index of Ethiopia is greater than unity for raw hide and skin export category compared with RCA index of all, which means Ethiopian in these categories can play important role and have significant potentiality in the export of raw hides and skins in the international market. However, in this category Kenya comes in the second position, Egypt and Tunisia holds third and fourth place respectively. In contrary, RCA index for leather and leather products exports Tunisia has high RCA index, among the four countries of this study, Kenya comes in the second position, Egypt and Ethiopia holds third and fourth place respectively However in Ethiopia a very promising trend has been observed, as index has been increased about 3,395\% in the last decade.

This study has revealed that Ethiopia has a potentiality to invest more and expand in leather industry which substantially is because of raw hide and skin exports. To strengthen this potential concerned governmental body, the entrepreneurs, investors and policy makers of the leather industry has to actively participate for proper implementation. If the investors and policy makers concentrate more on raw hides and skins category export, then country can earn more export revenue.

Moreover, leather goods sector should also be equally emphasized to keep its present growth and achieve a RCA index greater than unity. This is just a preliminary study on Ethiopian leather export on general catagory. Though two major categories of leather industry has been analyzed in this study, more in-depth analysis could be followed by this study, e.g. footwear industry, leather clothing, and other leather items.

\section{References}

[1] Shahab, S., \& Mahmood, M. T. (2013). "Comparative Advantage of Leather Industry in Pakistan with Selected Asian Economies", International Journal of Economics and Financial Issues 3(1), 133-139.

[2] Balassa, B. (1965). "Trade Liberalization and 'Revealed' Comparative Advantage", Manchester School of Economic and Social Studies, 33 (May), pp. 90-123.

[3] UNIDO, 2010, 'Future Trends in the World Leather and Leather Products Industry and Trade" United Nations industrial development organization, Vienna.

[4] CSA (Central statistical authority), (2004 \& 2007). Ethiopia Agricultural Sample Enumeration, statistical report on livestock population Addis Ababa, Ethiopia

[5] Altenburg, T. (2010) Industrial policy in Ethiopia. Discussion Paper / Deutsches Institut für Entwicklungspolitik. Retrieved from

http://dspace.cigilibrary.org/jspui/handle/123456789/28303

[6] Yeats, A. J. (1997), Does Mercosur's Trade Performance Raise Concerns about the Effects of Regional Trade Arrangements, International Economics Department, the World Bank.

[7] Sadaf Shahab1, Muhammad Tariq Mahmood 'Comparative Advantage of Leather Industry in Pakistan with Selected Asian Economies" International Journal of Economics and Financial Issues, Vol. 3, No. 1, 2013, pp.133-139

[8] Sapir, A. (1992). "Regional Integration in Europe." Economic Journal 102(415, November):1491-1506.

[9] Richardson, D. J., \& Zhang, C. (1999). "Revealing Comparative Advantage: Chaotic or Coherent Patterns across Time and Sector and U.S Trading Partner? National Bureau of Economic Research, Working Paper 7212.

[10] Bender S. \& Li Kui-Wai (2002). "The Changing Trade and Revealed Comparative Advantages of Asian and Latin American Manufacture Exports", Working Papers 843, Economic Growth Center, Yale University.

[11] Felix Chari, Bongani Muchanyuri and Macleans Mzumara, "Comparative Advantage of Ethiopia and the Role of International Purchasing" Greener Journal of Economics and Accountancy Vol. 2(2), pp. 051-057, June 2013.

[12] Mudavanhu, V., Mzumara, M. \& Tafirei, F. (2014). "Competitiveness of Kenyan industries in world trade", International Journal of Social Sciences and Entrepreneurship, 1 (9), 132-145.

[13] Paulina M. and Kenneth W. (2013) 'Factors affecting value addition in the leather industry in Kenya". European journal of business and innovation research, vol.1, no 3, pp. 45-55.

[14] Bouras H. (2013) "Specialization and imperative of diversification for Tunisian economics' 'Journal of Business Management and Economics Vol. 4(11). pp. 242-250. 
[15] Mahmoud Q. and Terry M. Amman,( 2009) "A mission for Accomplishment of a Comprehensive sector study regarding the opportunities of Complementarities and Industrial Integration in the Leather and Shoes Sector in the Member Countries of the Agadir Agreement ( Egypt - Jordan Morocco \& Tunisia), The Arab Mediterranean Free Trade Agreement, Agadir Technical Unit(ATU), Final Report.

[16] USAID/Cairo, Ministry of Foreign Trade "Impact of Trade and Economic Policy Reforms on Key Sectors of the Egyptian Economy”, Final Report, April 2004.

[17] African Development Bank Group - Eastern Africa Regional Resource Centre (EARC), 2014, 'Eastern Africa's Manufacturing Sector Promoting technology, innovation, productivity and linkages", Kenya.

[18] Mahmud, A. 2000. Development potential and constraints of hides and skins marketing in Ethiopia. In: R. C. Merkel, G. Abebe and A. L. Goetsch (eds.). The Opportunities and Challenges of Enhancing Goat Production in East Africa. Proceedings of a conference held at Debub University, Awassa, Ethiopia from November 10 to 12, 2000. E (Kika) de la Garza Institute for Goat Research, Langston University, Langston, OK pp. 127-138.

[19] Sonobe T., Akoten, J. E., \& Otsuka, K. 2009. An Exploration into the Successful Development of the Leather-Shoe Industry in Ethiopia. Review of Development Economics, 13(4), pp. 719-736.

[20] Loop T. van der. 2003. "The importance of the leather footwear sector for development in Ethiopia", RLDS Policy Brief No. 1, Addis Ababa University, Ethiopia.

[21] Central Statistical Agency, (CSA).1994. Report on Large and Medium Scale Manufacturing and Electricity Industries Survey. Addis Ababa, Ethiopia.
[22] Girum Abebe* and Florian Schaefer**. "High Hopes and Limited Successes: Experimenting with Industrial Polices in the Leather Industry in Ethiopia", EDRI Working Paper 011, December 2013, Ethiopian Development Research Institute and Department of Development Studies, SOAS (University of London)

[23] Balassa, B. (1977). "Revealed Comparative Advantage Revisited: An Analysis of Relative Export Shares of the Industrial Countries, 1953-1971", Manchester School of Economic \& Social Studies, 1977, vol. 45, issue 4, pp. 327-44.

[24] Balassa, B. (1979). "The Changing Pattern of Comparative Advantage in Manufactured Goods," Review of Economics and Statistics, 61 (May), pp. 259-266.

[25] Balassa, B. (1986). "Comparative Advantage in Manufactured Goods: A Reappraisal", the Review of Economics and Statistics, Vol. 68, No. 2, pp. 315-319.

[26] Batra A. \& Khan Z. (2005). "Revealed Comparative Advantage: An Analysis for India and China", Working Paper No 168, Indian Council for Research on International Economic Relations (ICRIER), New Delhi.

[27] Bender S., \& Li, Kui-Wai (2002). "The Changing Trade and Revealed Comparative Advantages of Asian and Latin American Manufacture Exports", Working Papers 843, Economic Growth Center, Yale University.

[28] Riaz, K., \& Jansen, H. G. P. (2012). "Spatial patterns of revealed comparative of Pakistan's agricultural exports", Pakistan Economic and Social Review, 50(2), 97-120.

[29] Ahmad, N. and Kalim, R. (2013). "Changing Revealed Comparative Advantage of Textile and Clothing Sector of Pakistan: Pre and Post Quota Analysis", Pakistan Journal of Commerce and Social Sciences, Vol. 7 (3), 520-544. 